\title{
PERKEMBANGAN PERUMAHAN PUBLIK DI NEGERI SAKURA: STUDI KASUS PADA PERUMAHAN DI TOKYO DAN SEKITARNYA
}

\author{
Nina Nurdiani \\ Architecture Department, Faculty of Engineering, Binus University \\ Jl. K.H. Syahdan No. 9, Palmerah, Jakarta Barat 11480 \\ nnurdiani@binus.edu
}

\begin{abstract}
Japan currently has been successful to provide housing for low to high-income people in urban areas. Almost everyone in Japan can access their homes, either public housing or private one, depending on the level of their welfare status. The study discusses about development of public housing in Japan and why the Japanese people can accept the design of the vertical housing built by their government. The study is conducted with descriptive approach through literature study and field observations in the city of Tokyo and its surrounding areas to provide knowledge about the development of public housing in Japan started from traditional residential and then developed into a modern residential horizontally and vertically according to the needs of his hometown community. Despite of the development from time to time, the design of residence still considers the local culture of Japan. So the Japanese people can receive residential design, although it is developed into vertical housing. This study is expected to give inputs for the Indonesian government as an effort to achieve the successful provision of public housing in Indonesia.
\end{abstract}

Keywords: development of Japanese residences, land cherry / Sakura country, public housing.

\begin{abstract}
ABSTRAK
Saat ini Jepang telah berhasil menyediakan perumahan untuk masyarakat berpenghasilan rendah hingga tinggi di wilayah perkotaannya. Hampir semua orang di Jepang dapat mengakses rumah mereka, baik perumahan publik maupun perumahan swasta, tergantung pada tingkat kesejahteraannya. Artikel ini membahas studi mengenai perkembangan perumahan publik di Jepang dan mengapa masyarakat Jepang dapat menerima rancangan perumahan vertikal yang dibangun oleh pemerintah Jepang, menggunakan pendekatan deskriptif melalui penelusuran literatur dan observasi lapangan di Tokyo dan sekitarnya. Dari hasil studi didapat kesimpulan bahwa meskipun mengalami perkembangan dari masa ke masa dan berkembang menjadi perumahan vertikal, rancangan hunian di Jepang tetap memperhatikan budaya masyarakat lokal, sehingga masyarakat Jepang tetap dapat menerima rancangan hunian tersebut. Studi ini diharapkan dapat memberi masukan bagi pemerintah Indonesia dalam upaya penyediaan perumahan publik di Indonesia.
\end{abstract}

Kata kunci: perkembangan perumahan Jepang, perumahan vertikal, budaya masyarakat Jepang. 


\section{PENDAHULUAN}

Rumah adalah cermin dari proses bermukim atau berhuni. Rumah merupakan suatu gejala struktural yang bentuk dan organisasinya sangat dipengaruhi oleh lingkungan budaya yang dimilikinya, serta erat hubungannya dengan kehidupan penghuninya (Rapoport, 1969). Dalam membangun rumah atau hunian, aspek yang diperhatikan tidak hanya aspek ekonomi, sosial, teknologi dan fisik, namun aspek budaya dari penghuni yang akan tinggal di rumah tersebut juga merupakan hal penting yang harus dipertimbangkan. Dari pernyataan di atas jelas terbaca bahwa budaya penghuni perlu diperhatikan dalam merancang hunian atau rumah tinggal. Manusia, lingkungan tempat tinggal dan budayanya merupakan kesatuan erat dan tidak terpisahkan. Apabila rancangan hunian baru dapat mewadahi ketiga hal tersebut, maka penghuni akan mudah beradaptasi dan dapat menerima tinggal di hunian baru tersebut.

Jepang merupakan Negara kepulauan yang terdiri dari tiga pulau besar dan pulau-pulau kecil di sekitarnya (Gambar 1). Lingkungan perkotaan di Jepang berada di lingkungan rawan gempa. Kondisi ini membuat rumah penduduk Jepang dirancang untuk bisa tahan terhadap gempa. Jumlah penduduk kota-kota di Jepang juga sangat tinggi, sedangkan luas lahan perkotaan di Jepang sangat terbatas. Karenanya perkembangan perumahan di perkotaan di Jepang dikembangkan dengan konsep hunian vertikal yang tetap kuat dan kokoh terhadap gempa (Gambar 2). Perpindahan cara berhuni masyarakat di Jepang dari hunian horizontal ke hunian vertikal tidak banyak menimbulkan masalah. Hampir seluruh lapisan masyarakat Jepang sepertinya mudah menerima rancangan hunian vertikal.

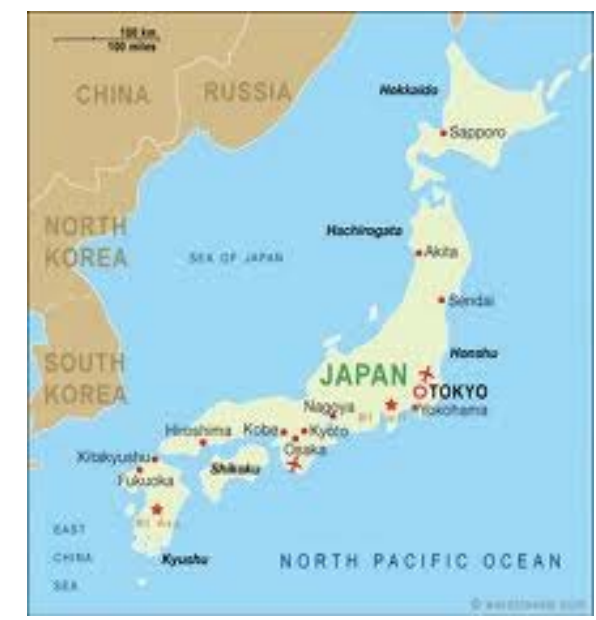

Gambar 1. Peta Jepang (Sumber: Google Map, 2011).

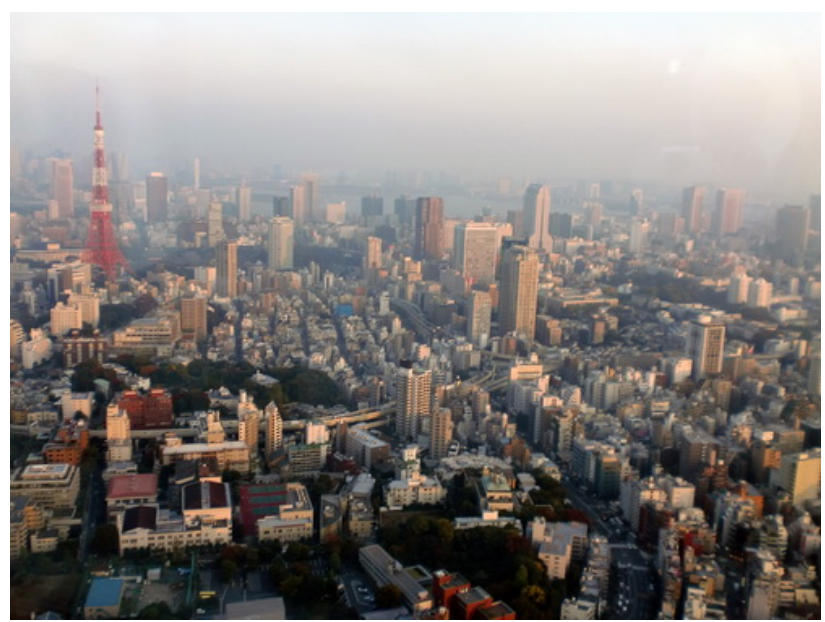

Gambar 2. Suasana lingkungan Tokyo (Sumber: Dokumen Pribadi, 2010).

Indonesia sebagai negara berkembang memiliki karakteristik yang hampir sama dengan Jepang yaitu berupa negara kepulauan bahkan lebih luas dari Jepang (Gambar 3). Indonesia juga memiliki budaya Timur dan berada di lokasi rawan gempa. Jumlah penduduk kota-kota di Indonesia sangat tinggi namun luas lahan kotanya sangat terbatas, sehingga kepadatan kota sangat tinggi (Gambar 4). Langkanya lahan di kota mempengaruhi harga hunian horizontal yang menjadi sangat mahal. Sudah hampir 30 tahun ini Indonesia giat mengembangkan hunian vertikal bagi penduduk kota. Hunian vertikal memberikan keuntungan pada penghuni untuk dapat tinggal di pusat kota dengan harga yang cukup terjangkau. Hunian vertikal untuk masyarakat menengah ke bawah di Indonesia dikembangkan dalam bentuk rumah susun sederhana. Meskipun ada subsidi dari pemerintah, masyarakat menengah ke bawah sepertinya belum bisa menerima tinggal di rumah susun sederhana. 
Sampai saat ini masih banyak unit hunian rumah susun sederhana yang dialihkan kepemilikannya atau penghuniannya.

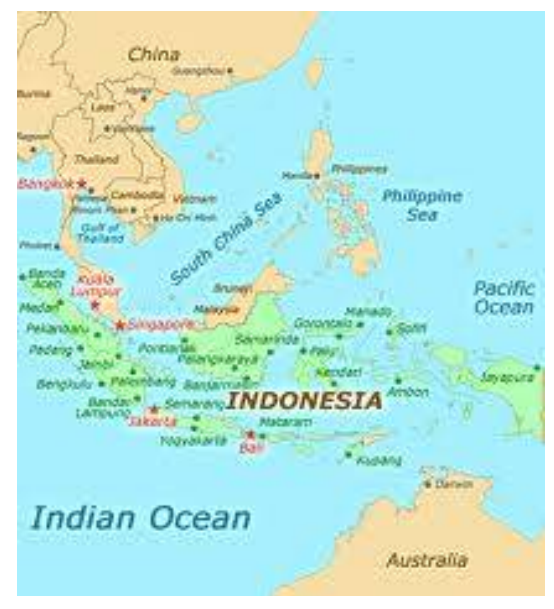

Gambar 3. Peta Indonesia (Sumber: Google Map, 2011).

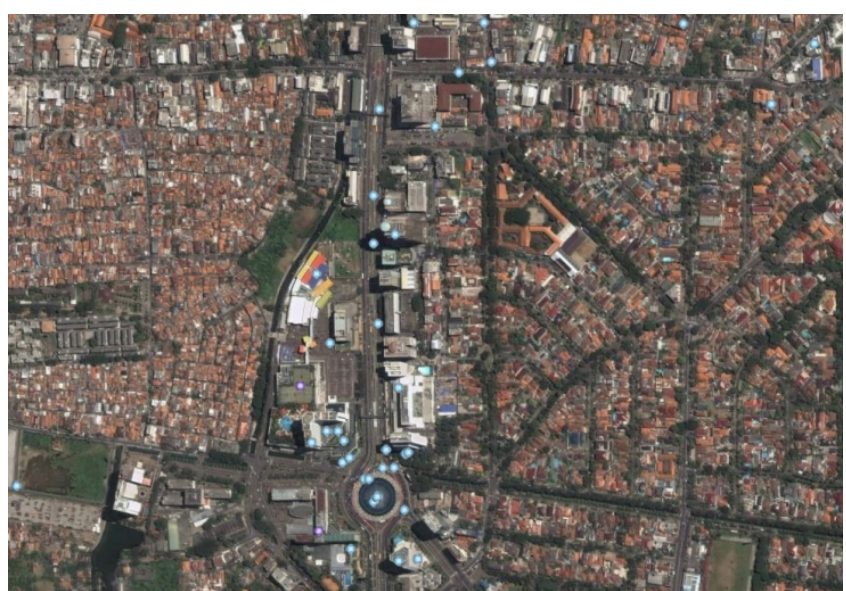

Gambar 4. Kepadatan lingkungan pusat kota Jakarta (Sumber: Google Map, 2007).

Sebagai negara maju, Jepang berhasil menyediakan perumahan bagi masyarakatnya di perkotaan, mulai dari masyarakat menengah ke bawah sampai masyarakat menengah ke atas. Hampir semua masyarakat di Jepang dapat mengakses perumahan, baik perumahan swasta maupun perumahan publik, sesuai dengan tingkat kesejahteraan masyarakatnya. Namun melalui sejarah terlihat bahwa Jepang juga mengalami kondisi kekurangan penyediaan perumahan publik di kota, seperti juga di Indonesia. Bahkan Jepang mengalami kondisi yang lebih parah yaitu krisis setelah peristiwa pengeboman kota Nagasaki dan Hiroshima. Dengan latar belakang demikian dan kondisi negara yang sering dilanda gempa sepanjang perjalanan sejarahnya, tentunya tidak mudah meyakinkan masyarakat kota di Jepang untuk tinggal di hunian vertikal. Melihat keberhasilan Jepang, Indonesia sebagai negara berkembang dapat belajar dari pengalaman negara tersebut dalam menyediakan perumahan publik untuk semua lapisan masyarakat.

Studi perkembangan perumahan publik di Jepang perlu dilakukan dengan tujuan untuk mempelajari bagaimana perkembangan perumahan publik di Jepang dan mengapa masyarakat Jepang dapat menerima rancangan perumahan vertikal yang dibangun oleh pemerintah Jepang. Studi mengenai perkembangan perumahan publik di Jepang perlu dilakukan untuk memberi masukan bagi pemerintah Indonesia dalam upaya mencapai keberhasilan penyediaan perumahan publik di Indonesia, khususnya penyediaan hunian vertikal di perkotaan yang sampai saat ini masih belum bisa diterima dengan baik oleh masyarakat golongan menengah ke bawah dan masih banyak terjadi pengalihan penghunian.

\section{METODE}

Studi tentang perkembangan perumahan publik di Jepang dan mengapa masyarakat Jepang dapat menerima rancangan perumahan vertikal yang dibangun oleh pemerintah Jepang dilakukan dengan pendekatan deskriptif. Metode pengambilan data dilakukan dengan studi literatur dan pengamatan di lapangan yang direkam melalui foto di Tokyo dan sekitarnya selama dua bulan, yaitu November-Desember 2010 (Gambar 5). Analisis deskriptif dilakukan terhadap berbagai sumber literatur yang menjelaskan sejarah perkembangan perumahan publik di Jepang dan bagian-bagian penting dari hunian tradisional Jepang. Kemudian dilakukan analisis deskriptif yang melihat 
penerapan bagian-bagian penting dari hunian tradisional pada rancangan hunian vertikal modern yang difokuskan pada bentuk arsitektur atau ruang-ruang apa saja dari hunian tradisional yang masih tetap dipertahankan.

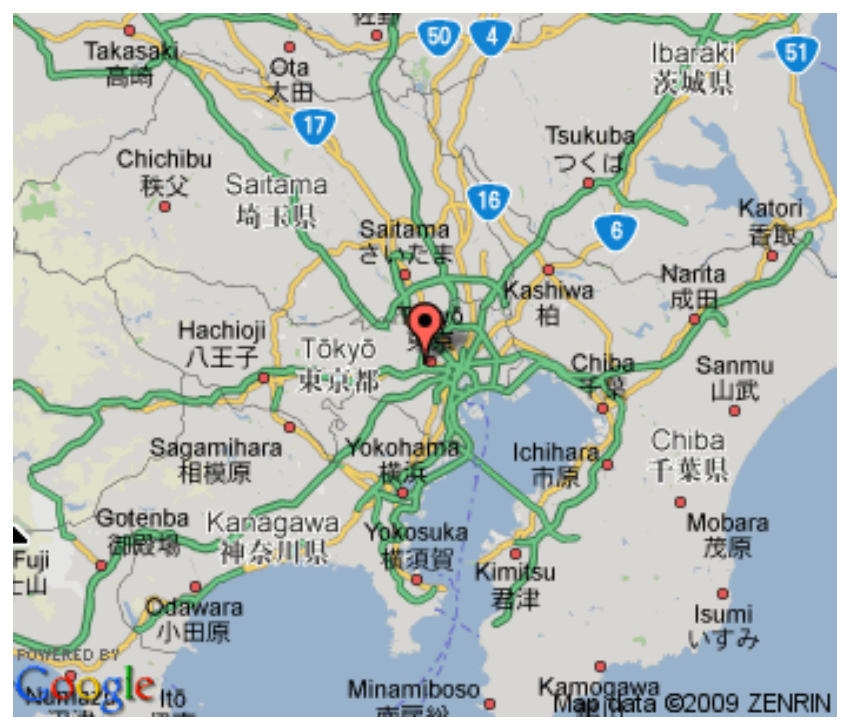

Gambar 5. Peta lokasi pengamatan di Tokyo dan sekitarnya (Sumber: Google Map, 2010).

Pengamatan lapangan dilakukan pada hunian vertikal modern di Roka Terrace Gated Community - Tokyo, Tama Town House - Kanagawa, manshon di Kawasaki - Tokyo, dan Chigusadai Danchi - Chiba (Gambar 6). Keempat hunian modern ini terpilih untuk mewakili jenis hunian vertikal modern yang berkembang di Jepang saat ini. Masyarakat atas menggemari hunian dengan rancangan tipe manshon dan gated community. Sedangkan masyarakat menengah ke bawah (di Jepang hanya sedikit masyarakat golongan bawah) lebih menyenangi town house dan apato atau danchi. Apato, manshon, dan gated community berada dekat pusat kota seperti di Tokyo. Sedangkan town house dan danchi berada di pinggir kota Tokyo seperti di Chiba dan Kanagawa.

\section{HASIL DAN PEMBAHASAN}

\section{Tinjauan Sejarah Perumahan Publik di Jepang}

Penjelasan di bawah ini adalah sejarah mengenai perkembangan perumahan Jepang yang disajikan oleh U.N. International Year of Shelter for the Homeless dan berbagai sumber lainnya.

\section{Perkembangan Sosial, Ekonomi dan Situasi Kehidupan}

Sebelum tahun 1910, Urbanisasi tidak membuat kemajuan yang berarti di Jepang. Sistem feodal dan pertanian memimpin struktur ekonomi saat itu. Perumahan masih berbentuk rumah tradisional.

\section{0 - 1945 Periode Taisho Menuju Masa Pra-Perang Dunia dan Masa Perang Dunia}

Pada tahun 1910, Perang Dunia I mendorong industrialisasi yang menyebabkan urbanisasi para pekerja ke kota. Hal ini berakibat pada tidak terpenuhinya kebutuhan perumahan di perkotaan. 
Banyak orang yang hidup di bawah standar dan tinggal di daerah kumuh yang tidak sehat. Jepang memasuki abad modern sekitar tahun 1920-an, saat perencanaan kota modern dan sistem konstruksi beton bertulang mulai diperkenalkan di Jepang. Pada saat itu tahapan pertama perkembangan hunian modern di Jepang dimulai, dimana aspek teknologi dan kebijakan perumahan mulai dilaksanakan dan dikembangkan. Pada tahun 1930, Jepang kembali memasuki masa perang yang menyebabkan perumahan berada di bawah standar kelayakan (Tokyo Metropolitan Government, 1987).

Sebelum masa perang di Jepang, tipe rumah yang banyak berkembang di kota-kota di Jepang adalah tipe rumah machiya dan nagaya. Machiya adalah hunian yang memiliki dua sisi yang terbuka di depan dan di belakang yang dikembangkan untuk menciptakan lingkungan berkepadatan tinggi di perkotaan. Bentuk ini berkembang sebagai rumah toko di Jepang yang banyak terdapat di lokasi-lokasi dekat pusat keramaian seperti pasar, pelabuhan, dan lain sebagainya. Nagaya adalah hunian sewa dengan sumur dan toiletnya yang dirancang untuk bersama, yang dibangun untuk para pekerja di daerah perkotaan dibawah kendali para pemimpin kota pada periode Edo. Pada periode ini berkembang pula rumah untuk kelompok penghuni kelas menengah berukuran $70 \mathrm{~m}^{2}-200 \mathrm{~m}^{2}(20-$ 70 tsubo) dengan gaya modern dimana mulai dikenalkan gaya hidup barat yaitu kegiatan atau aktifitas di dalam rumah menggunakan kursi dan meja, lantai mulai diberi penutup lantai, area dapur mulai dikenalkan peralatan modern seperti lemari es dan mesin cuci (Tokyo Metropolitan Government, 1987).

\section{5 - 1954 Periode Rehabilitasi Pasca-Perang}

Perang menyebabkan jutaan rumah terbakar. Di tengah suplai perumahan yang sangat kurang memadai, banyak orang di daerah perkotaan yang tinggal di gubuk-gubuk atau tempat penampungan. Aliran udara yang sangat sedikit, pengap, dan kepadatan sangat tinggi menyebabkan banyak masyarakat yang terserang penyakit. Pemerintah akhirnya mengembangkan tempat tinggal darurat dengan tipe standar (6,25 tsubo / 20,63 $\mathrm{m}^{2}$ ). Pada tahun 1947-1949 kehidupan masyarakat mulai meningkat, pernikahan banyak terjadi yang berakibat tingginya angka kelahiran di Jepang (sering disebut "generasi baby boom"). Rata-rata tingkat sewa perumahan menurun di perkotaan setelah perang, karena manajemen perumahan sewa tidak praktis.

\section{5 - 1964 Periode Awal Pertumbuhan Ekonomi Cepat}

Selama periode ini, Jepang membuat lompatan besar menuju era baru dengan standar-standar kehidupan, kemajuan yang luar biasa dan perubahan yang banyak. Revolusi Konsumsi (consumer goods: peralatan rumah tangga listrik) menyebar dengan cepat dan meluas. Hal ini memicu peningkatan pasar tenaga kerja. Banyak orang berpindah dari daerah pedesaan ke perkotaan. Sejumlah besar rumah-rumah apartemen dari kayu milik swasta dibangun selama periode ini.

The Japan Housing Corporation (JHC) didirikan untuk membangun kompleks perumahan dengan tujuan memenuhi kekurangan perumahan akibat urbanisasi yang meningkat. Urbanisasi ini juga mendorong berkembangnya keluarga inti. Apartemen sewa dari kayu (dengan fasilitas sendiri [18.4\%] atau fasilitas bersama [25,3\%]) merupakan rumah-rumah yang mayoritas dibangun pada periode ini untuk memenuhi pertumbuhan populasi di wilayah perkotaan.

\section{5 - 1974 Periode Akhir Pertumbuhan Ekonomi Cepat}

Sebagai hasil dari pertumbuhan cepat yang menerus terjadi di Jepang, standar-standar konsumsi masyarakat meningkat menyesuaikan dengan di Eropa dan Amerika Serikat. Orang-orang mulai membeli barang-barang berkualitas tinggi dalam jumlah besar dan mencari pendidikan tinggi. Namun pencemaran lingkungan dan penyakit yang disebabkan oleh polusi membayangi kesejahteraan dan mengancam kehidupan masyarakat. 
Pada periode ini, lompatan harga tanah di daerah perkotaan membuat perumahan dibangun vertikal dengan harga tinggi dan kepadatan tinggi. Ini memberikan pengaruh negatif terhadap lingkungan sekitarnya; memicu timbulnya masalah sosial dan tindakan protes dari masyarakat. Banyak orang pindah ke daerah sub-urban dan membeli atau membangun rumah horisontal yang terpisah. Setelah mencapai kemakmuran secara materi, Jepang kembali ditekan untuk mengkoreksi kekuatan ekonominya.

\section{5 - 1990 Periode Pertumbuhan Ekonomi Stabil}

Ekonomi Jepang telah berada di jalan yang stabil. Perhatian masyarakat atas standar hidup mulai beralih dari kuantitas menjadi pada kualitas. Orang-orang mengejar kehidupan sesuai selera mereka.Kehidupan masyarakat masih sedikit memiliki masalah sosial dan masalah keluarga. Peningkatan populasi lanjut usia dan keluarga inti telah meningkatkan jumlah rumah tangga lanjut usia, yang menyebabkan kekurangan perumahan bagi mereka.

\section{0 - Sekarang, Periode Ekonomi Maju}

Ekonomi Jepang telah berada dalam kondisi stabil dan maju. Perhatian masyarakat fokus pada standar kualitas kehidupan yang tinggi, khususnya dalam penggunaan material bangunan, penyelesaian pekerjaan material pada unit hunian dan bangunan. Masyarakat juga peduli terhadap konsep eco-living untuk lingkungan yang berkelanjutan. Mereka menerapkan konsep ini dalam kegiatan dan perilaku mereka sehari-hari. Tantangan bagi Jepang saat ini adalah perbandingan populasi anak-anak dan lansia yang tinggi. Kehidupan wanita karir lajang yang meningkat di Jepang menyebabkan menurunnya angka kelahiran. Tingginya kualitas kesehatan di Jepang menyebabkan menurunnya angka kematian.

Saat ini di Jepang banyak mengembangkan proyek mix used redevelopment, terutama di kota Tokyo dan kota besar lainnya di Jepang. Pada proyek ini hunian publik vertikal berintegrasi dengan fungsi penunjang (stasiun kereta api atau halte bus) dan fungsi komersial (pusat perbelanjaan atau kantor) yang dirancang menjadi sangat modern ditambah lagi dengan fungsi-fungsi baru yang berkembang yang sebelumnya belum ada pada hunian tradisional Jepang pada umumnya (Cybriwsky, 1991). Hunian vertikal maupun hunian horisontal di Jepang terus berkembang seiring dengan meningkatnya kebutuhan dan kualitas hidup penduduknya yang semakin modern.

\section{Rumah Tradisional Jepang}

Pengembangan bentuk arsitektur pada rumah Jepang dimulai dari tradisi "tinggal di atas lantai (to live on the floor)". Hampir semua aktifitas harian pada kehidupan tradisional di Jepang menggunakan lantai dasar tanpa perabot. Kegiatan makan, tidur, menyiapkan makanan, bermain dan lain sebagainya dilakukan di atas lantai. Penggunaan kursi baru dikenalkan saat masuknya budaya China dan Eropa di abad ke-20. Penggunaan kursi hanya dapat diterima oleh masyarakat atas, sedangkan masyarakat bawah belum dapat menerima budaya ini saat itu. Pada banyak budaya, kursi menandakan tingkatan sosial. Lantai dengan tatami mats (anyaman tikar) umumnya digunakan pada hunian tradisional di Jepang (Locher, 2010).

Rumah tradisional Jepang tidak memiliki ruang-ruang dengan satu fungsi khusus, kecuali genkan (area pintu masuk), dapur, kamar mandi dan toilet/WC. Beberapa ruang umumnya digunakan untuk beberapa fungsi menjadi ruang duduk, ruang makan, ruang belajar atau ruang tidur. Hal ini dimungkinkan karena semua perabot pada rumah Jepang umumnya dapat dilipat, dipindahkan atau disimpan dalam oshiire (bagian kecil dari sisi ruang yang digunakan untuk menyimpan barang). 
Pemisahan ruang dalam rumah Jepang diciptakan melalui penggunaan fusuma (pintu geser yang terbuat dari kayu atau kertas tembus cahaya) yang mudah diangkat dan dipindahkan. Dengan fusuma dapat tercipta ruang kecil dalam rumah yang dapat digunakan untuk fungsi lain. Pada saat diperlukan ruang yang lebih besar, partisi-partisi dapat dilepas sehingga tercipta satu ruang besar.

Pada dasarnya satu unit rumah tradisional Jepang yang lengkap terdiri dari dapur, kamar mandi dan toilet/WC, genkan dan satu ruang multifungsi yang berada dibawah satu atap. Atap rumah tradisional Jepang terbuat dari kayu dan genteng keramik. Kadang-kadang area dapur dapat menjadi area komunal, bahkan masih bisa ditemukan rumah Jepang yang sangat minimal dan murah yang disewakan yang hanya terdiri dari genkan dan satu ruang.

\section{Hunian Modern di Tokyo dan Sekitarnya}

Jepang yang terkenal sebagai negeri Sakura memiliki kota dengan populasi penduduk terbesar di dunia, yaitu kota Tokyo. Tokyo dan wilayah sekitarnya seperti Chiba, Kanagawa, Saitama, Yamanashi dapat menjadi model yang baik yang memperlihatkan keberhasilan pemerintah Jepang menyediakan perumahan bagi masyarakatnya.

Melihat kembali sejarah perkembangan perumahan modern di Jepang, sebelum tahun 1968 adalah tahun dimana masyarakat perkotaan di Jepang hidup di lingkungan yang kurang baik dan di bawah standar perumahan yang sehat dan layak huni. Setelah periode ini, Pemerintah Jepang membuat lompatan baru dalam pengembangan perumahan bersamaan dengan masuknya simbol kehidupan modern, yaitu tiga alat rumah tangga modern (televisi, mesin cuci dan lemari es). Masuknya ketiga peralatan modern ini merubah gaya hidup masyarakat Jepang, khususnya yang tinggal di perkotaan. Kehidupan menjadi lebih praktis karena perkembangan teknologi peralatan rumah tangga semakin meningkat dengan membuat peralatan serba menggunakan tombol, multi fungsi, dan ukuran yang lebih kecil dari sebelumnya. Penghuni rumah tidak memerlukan banyak tempat untuk menyimpan peralatan rumah tangga mereka. Waktu mengerjakan pekerjaan rumah tangga menjadi lebih singkat dari sebelumnya.

Pengembangan hunian dan perumahan modern di Jepang saat ini, baik yang disewakan maupun dimiliki sendiri oleh penghuni, tidak lepas dari pengaruh asing (Amerika dan Inggris). Hunian yang berkembang di Jepang antara lain apartemen (apato), kondominium (manshon), flat, perumahan untuk pekerja, perumahan publik (danchi), rumah tunggal (detached house), co-op house dan lain sebagainya. Meskipun dipengaruhi budaya asing, ukuran ruang pada hunian masih menggunakan standar lokal yaitu unit tsubo (1 tsubo $=2$ tatami mats atau sekitar $\left.3.3 \mathrm{~m}^{2}\right)$.

Unit hunian modern di Jepang biasanya dibedakan berdasarkan jumlah ruang dan jenis ruang yang tersedia pada setiap tipe unit hunian, misalnya $1 \mathrm{R}$ atau $2 \mathrm{LDK}$. R menandakan room (ruang), $\mathrm{L}$ adalah living room (ruang duduk). D adalah dining room (ruang makan), dan $\mathrm{K}$ adalah kitchen (dapur). Angka 1, 2 atau 3 menandakan jumlah ruang yang tersedia untuk fungsi yang beragam. Umumnya ruang-ruang dalam unit hunian dipisahkan oleh fusuma yang mudah dipindah-pindah atau digeser dari satu sisi ke sisi lainnya. Dengan demikian satu ruangan yang lebih besar dapat tercipta apabila pintu gesernya di buka atau di angkat. Yang paling penting lagi dari hunian di Jepang, ruang duduk menggunakan tatami mats yang terbuat dari anyaman tikar dengan ukuran $180 \mathrm{~cm}$ x $90 \mathrm{~cm}$.

Dari hasil pengamatan lapangan pada hunian vertikal modern di Roka Square Gated Community - Tokyo, Tama Town House - Kanagawa, manshon di Kawasaki, dan Chigusadai Danchi - Chiba terlihat bahwa hampir semua rancangan hunian memiliki ruang-ruang yang terdapat pada rumah tradisional Jepang. Ini memperlihatkan bahwa rancangan hunian modern tetap melestarikan dan menerapkan nilai-nilai budaya lokal yang menjadikan penghuni merasa nyaman dan tetap dekat dengan kearifan lokal yang dimiliki oleh masyarakat Jepang pada umumnya. 
Berikut penjelasan yang memperlihatkan penerapan bagian-bagian dari hunian tradisional Jepang pada hunian vertikal modern di Jepang:

\section{Genkan}

Rumah tradisional Jepang biasanya memiliki genkan yaitu area penerima setelah pintu masuk rumah. Pada hunian vertikal modern genkan masih disediakan dekat pintu masuk (lihat gambar 4). Ini merupakan area yang tidak luas dan tinggi permukaan lantainya sama dengan area teras luar. Di area ini penghuni atau orang luar akan melepas sepatu mereka dan menggantinya dengan sandal rumah. Kemudian mereka meletakkan sepatu di lemari kabinet yang disebut getabako yang terletak dekat genkan. Hal ini dilakukan sejak dulu turun temurun, dimana sandal luar/sepatu diletakkan dengan rapi di genkan dan diganti dengan sandal rumah untuk menjaga kebersihan dalam area rumah.
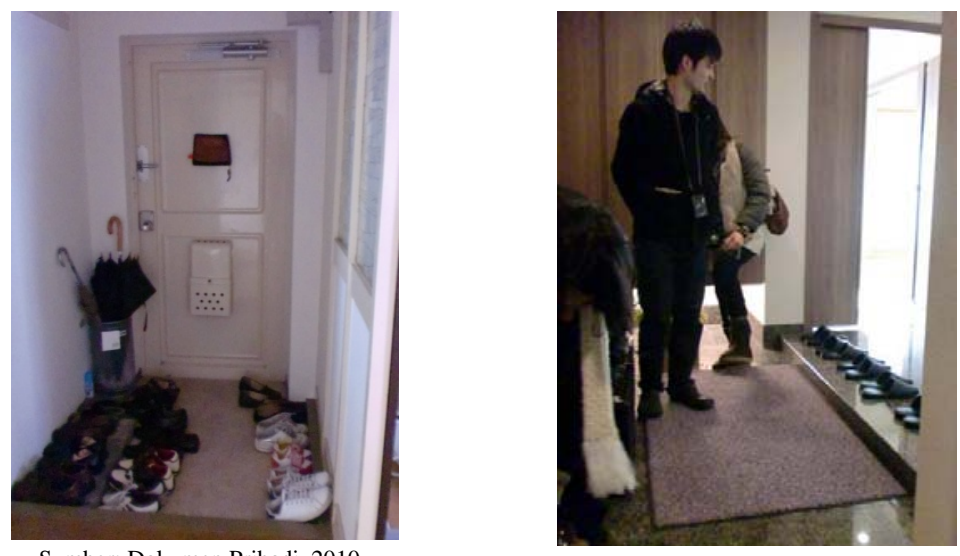

Gambar 6. Genkan pada hunian danchi (kiri) dan hunian manshon (kanan).

\section{Toilet (WC/Kakus) dan Kamar Mandi}

Toilet (WC/kakus) pada hunian modern prinsip penerapannya sama dengan penerapan toilet pada rumah tradisional Jepang, yaitu ditempatkan terpisah dari ruang untuk mandi. Apabila luas hunian tidak besar dan ruangan yang tersedia sangat sempit, toilet dapat dijadikan satu dengan ruang mandi dalam satu ruang yang kecil namun efisien. Mengikuti kebiasaan tradisional juga, ketika penghuni masuk toilet, penghuni juga mengganti sandal rumah mereka dengan sandal plastik untuk di toilet atau di kamar mandi. Pada rumah Jepang pemisahan ruang untuk mandi dan toilet adalah biasa. Apartemen yang sempit ruangannya tetap memiliki ruang mandi yang kecil dan ruang untuk tempat mesin cuci.

\section{Dapur}

Dapur pada rumah tradisional Jepang belum memiliki peralatan memasak yang modern. Sedangkan pada dapur Jepang modern biasanya sudah dilengkapi perlengkapan untuk memasak (kompor gas/listrik, microwave/oven, alat pemanggang), bak cuci (untuk mencuci bahan makanan), exhaust fan (penghisap udara panas), dan lemari es. Pipa air juga sudah tersambung lengkap dengan mesin pemanas (heater) untuk persiapan di musim dingin.

\section{Washitsu}

Rumah Jepang memiliki ruang bergaya tradisional Jepang yang disebut washitsu (Gambar 7). Ruang ini merupakan ruang dengan lantai tatami (lantai dari anyaman tikar), memiliki shoji (pintu atau jendela geser tambahan terbuat dari kertas tembus cahaya) untuk mengurangi silau cahaya 
matahari yang masuk melalui pintu atau jendela. Washitsu juga memiliki fusuma (pintu geser yang ringan dan dapat digeser) yang memisahkan ruang satu dengan ruang yang lain, memiliki oshiire (tempat penyimpanan di dinding yang terbagi dua atau tiga bagian) untuk menyimpan futon (alas tidur dan selimut tidur), dan memiliki plafon/langit-langit terbuat dari kayu. Ruang ini tidak dipenuhi perabot dan berfungsi sebagai ruang keluarga pada siang hari, sedangkan malam hari menjadi ruang tidur. Banyak washitsu yang memiliki pintu geser dari kaca yang terbuka pandangannya ke balkon.

Masyarakat Jepang menganut nilai-nilai lokal terkait dengan keberadaan ruang washitsu. Mereka masih menggunakan ruang ini untuk kegiatan harian mereka. Sehingga rumah Jepang modern sekurang-kurangnya harus memiliki satu ruang washitsu. Ruang lainnya seperti ruang duduk, ruang makan, dapur dan lainnya dapat saja bergaya barat. Penghuni biasanya menyenangi lantai dari bahan sintetic demikian juga untuk plafonnya. Warna yang dipilih mereka juga lebih banyak yang berwarna putih atau krem. Bentuk jendela yang disenangi juga lebih banyak berupa jendela yang dapat digeser.

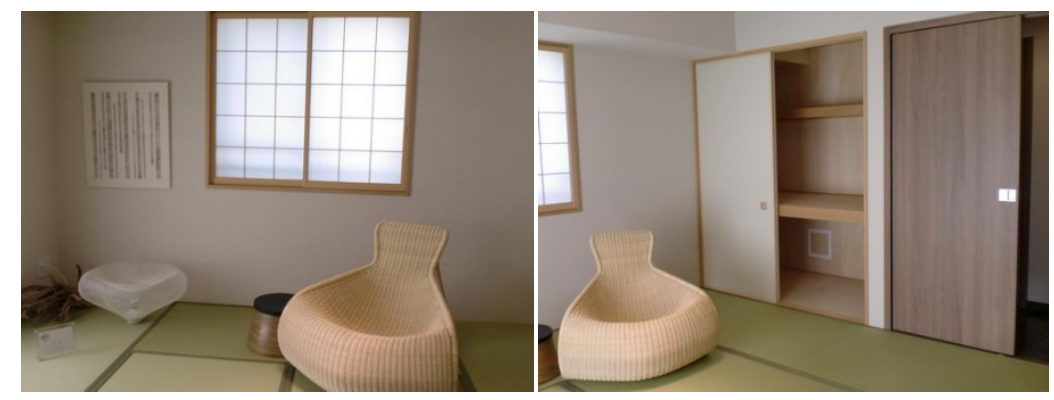

Gambar 7. Washitsu pada hunian modern Jepang (Sumber: Dokumen Pribadi, 2010).

Saat ini rancangan unit hunian apartemen cukup banyak dan bervariasi, namun demikian rancangan ruang tetap mengadopsi pola susunan ruang yang lama. Misalnya untuk penghuni tunggal adalah rancangan ruang yang panjang dan ramping dengan dapur dan kamar mandi (ruang closet terpisah dengan ruang mandi) diletakkan dekat genkan, dan ruang duduk atau ruang tidur di tepi ruang dekat balkon. Sedangkan untuk keluarga rancangan ruang hunian tidak memanjang tetapi menyesuaikan dengan bentuk apartemennya. Apabila penghuni memiliki kendaraan, mereka dapat menggunakan ruang parkir baik di dalam apartemen atau di area parkir bersama di lingkungan sekitar perumahan dengan membayar sewa ruang parkir.

Sistem struktur dan konstruksi serta material bahan bangunan dan furnitur pada hunian modern Jepang juga mempertimbangkan kondisi geografi negara sakura tersebut yang sering dilanda gempa. Umumnya sistem struktur yang digunakan harus kuat menahan gempa besar ataupun gempa kecil yang sering terjadi. Umumnya struktur dinding hanya sebagai pengisi dari sistem struktur utama. Material bahan bangunan dan furnitur terbuat dari bahan yang ringan, tipis, mudah perawatan dan pemeliharaannya, juga kuat dan kokoh menahan beban serta tahan lama. Orientasi bangunan pada area balkon dihadapkan ke sisi dimana sinar matahari maksimal didapatkan. Pada beberapa wilayah yang mendapat salju di musim dingin, desain hunian memperhatikan kemudahan dan kenyamanan penghuni untuk menjalankan aktifitas hariannya di dalam rumah dan di luar rumah. Seperti terlihat pada Gambar 8, penggunaan kaca ganda pada balkon membantu menghangatkan ruangan di musim dingin namun tetap mendapatkan cahaya matahari, pintu masuk dirancang langsung menuju lantai dua dari unit hunian untuk mengantisipasi tingginya salju pada musim dingin yang bisa mencapai $2-3 \mathrm{~m}$ dari permukaan tanah, arcade pada bagian depan hunian untuk memudahkan aksesibilitas pedestrian di musim dingin. 


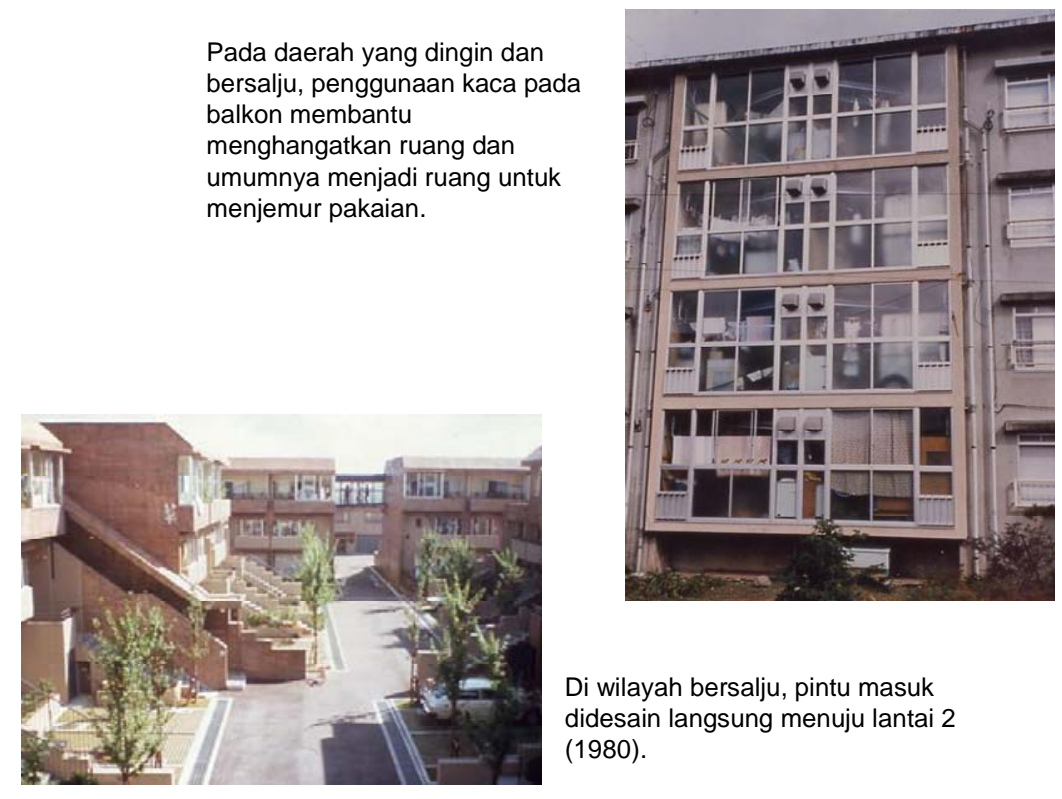

Gambar 8. Rancangan fasade hunian modern Jepang yang memperhatikan kondisi iklim dan lingkungan setempat (Sumber: Kobayashi, 2008).

Dari hasil pengamatan di lapangan, khususnya hunian modern di kota besar seperti Tokyo dan sekitarnya, ternyata penerapan nilai-nilai lokal dikemas dalam bentuk fisik yang hampir sama dengan yang lama, tapi kualitas materialnya lebih baik. Meskipun gaya hidup modern mengelilingi masyarakat perkotaan di Tokyo dan sekitarnya, kepedulian masyarakat Jepang sangat tinggi terhadap penerapan budaya lokal dalam rancangan huniannya. Sampai saat ini, hampir semua unit hunian modern memiliki satu ruang dengan lantai tatami. Budaya "tinggal di atas lantai" ini masih tetap dilestarikan oleh masyarakat Jepang sampai saat ini. Budaya ini mendukung konsep sustainability karena ruang-ruang pada hunian modern di Jepang tidak berlebihan luasnya dan sesuai kebutuhan penghuninya yang hidup praktis. Masyarakat Jepang tidak banyak menyimpan perabotan, bahkan dengan konsep hidup di atas lantai pada ruang-ruang yang multifungsi membuat luas hunian di Jepang relatif kecil, dan beban hunian menjadi lebih ringan sehingga bisa mendukung upaya mewujudkan hunian yang tahan gempa (Gambar 9).

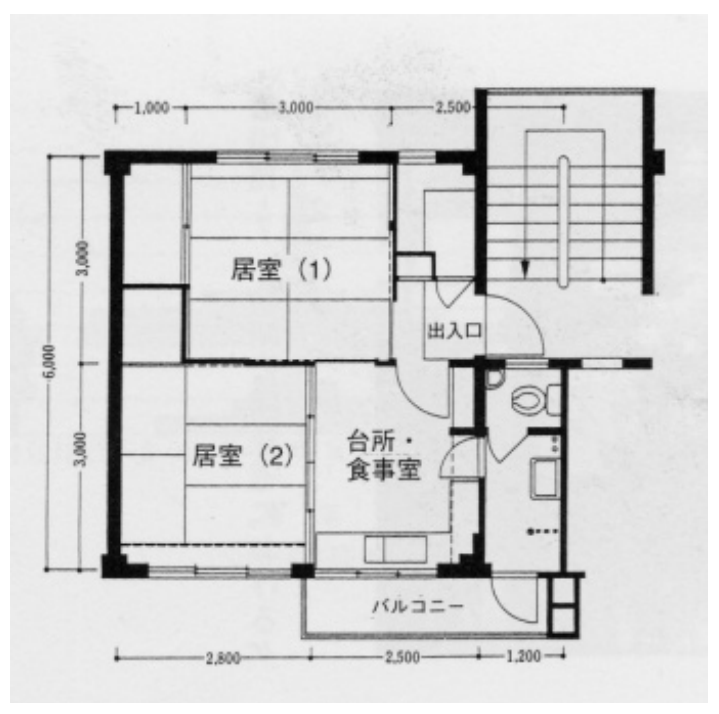

Gambar 9. Standar perencanaan untuk unit hunian pada perumahan publik (Sumber: Kobayashi, 2008). 
Pada hunian modern Jepang, tidak banyak ruang yang terbuang untuk sirkulasi atau menyimpan barang. Kegiatan makan, tidur, menyiapkan makanan, bermain dan lain sebagainya masih dilakukan di atas lantai sampai saat ini. Hal ini sesuai dengan yang dinyatakan oleh Locher (2010) bahwa masyarakat Jepang memiliki nilai-nilai budaya yang kuat melalui konsep tinggal di atas lantai. Seperti yang dinyatakan oleh Soeroto (2003) bahwa perkembangan teknologi dan ilmu pengetahuan, serta pertumbuhan ekonomi yang meningkat adalah bagian dari proses modernisasi yang seyogyanya tidak menggugurkan nilai-nilai tradisi yang sudah lama terbentuk. Merujuk pada pernyataan tersebut dan melihat rancangan hunian modern di Jepang khususnya hunian vertikal, bisa dipastikan bahwa nilai-nilai lokal tetap hidup di tengah masyarakat Jepang dalam kehidupannya sehari-hari di Jepang, karena rancangan hunian vertikal yang baru tetap memperhatikan kearifan lokal. Mengacu pada pernyataan Rapoport (1969) terlihat jelas bahwa apabila terdapat kesatuan erat antara manusia, lingkungan tempat tinggal dan budayanya, maka keharmonisan akan terjadi dan kehidupan manusia dalam rumahnya dalam rangka meningkatkan kualitas kehidupannya akan berlangsung dengan baik.

Perbedaan mendasar antara budaya di Indonesia dengan budaya di Jepang yang mempengaruhi perbedaan penerimaan penghuni terhadap hunian vertikal. Masyarakat Jepang lebih mudah beradaptasi dengan hunian vertikal karena rancangan hunian vertikal yang baru memperhatikan kebutuhan penghuni dan menerapkan budaya lokal dalam rancangan huniannya. Budaya berhuni di Jepang sejak masa lalu sudah terbiasa dengan pola ruang multifungsi dengan sedikit perabotan yang mudah dipindahkan dan disimpan, serta mereka jarang bersosialisasi dengan tetangga di dalam rumahnya. Mereka memanfaatkan masa-masa berkumpul di taman bunga saat merayakan musim semi dan musim gugur, atau berkumpul di restoran dengan teman kerja atau tetangga. Sedangkan di Indonesia, budaya berhuni cenderung mengacu pada keluarga besar (bukan keluarga inti), terbiasa menyimpan barang sebagai bekal hidup atau untuk diwariskan, dan terbiasa menerima tamu atau bersosialisasi. Budaya yang berbeda ini memberikan penerimaan yang berbeda pada rancangan hunian vertikal yang terbatas luas dan jumlah ruangnya. Sehingga masyarakat Indonesia tidak mudah menerima rancangan hunian vertikal. Ditambah lagi rancangan hunian vertikal di Indonesia belum atau kurang memperhatikan budaya bermukim masyarakat Indonesia, lebih banyak mengadopsi standar-standar dari luar Indonesia yang belum tentu sesuai dengan kebiasaan masyarakat Indonesia.

Melihat dari perkembangan hunian publik di Jepang dan penerapan budaya lokal pada rancangan hunian vertikal modern di Jepang, Indonesia dapat belajar untuk menggali nilai-nilai budaya lokal yang nantinya dapat diterapkan pada hunian vertikal modern di Indonesia yang sesuai dengan kebutuhan masyarakat kota di Indonesia. Tentunya rancangan hunian vertikal modern tersebut adalah yang khas dan sesuai untuk kondisi iklim dan budaya di Indonesia dan berbeda dengan rancangan hunian di Jepang atau dengan negara lainnya di dunia. Rancangan hunian tersebut tidak hanya mengolah fasade bangunan saja agar terlihat modern, tapi juga mengolah tata ruang dalam hunian sebagai wadah tempat tinggal bagi penghuni untuk beraktifitas sehari-hari dan meningkatkan kualitas kehidupannya.

\section{PENUTUP}

Jepang telah berhasil menyediakan perumahan untuk masyarakat berpenghasilan rendah hingga tinggi di wilayah perkotaan, seiring sejarah perkembangan hunian di Jepang. Hampir semua orang di Jepang dapat mengakses ke rumah mereka, baik perumahan umum dan perumahan swasta tergantung pada tingkat kesejahteraan mereka. Keberhasilan penyediaan perumahan di Jepang didukung oleh program yang jelas, peraturan yang ketat untuk pembangunan perumahan, dan dukungan finansial dari pemerintah nasional. Pembangunan perumahan di Jepang juga menyesuaikan dengan kondisi sosial ekonomi penduduk di Jepang, keterbatasan lahan kota di Jepang, dan konsep berkelanjutan dalam penggunaan bahan bangunan pada pembangunan perumahan. 
Pembangunan perumahan di Jepang dari masa ke masa terus meningkat dari sisi teknologi, sehingga saat ini banyak hunian dibangun dengan menggunakan bahan yang ringan, kuat dan tahan lama. Meskipun demikian, nilai-nilai budaya lokal masih tetap diterapkan dalam rancangan hunian modernnya. Washitsu, Genkan, fusuma, shoji dan tatami adalah bagian-bagian dari bentuk arsitektur tradisional Jepang yang masih diterapkan dalam rancangan hunian modern untuk hampir semua lapisan masyarakat di Jepang saat ini baik masyarakat menengah ke bawah maupun masyarakat menengah ke atas, yang diterapkan pada hunian horisontal maupun hunian vertikal. Dengan kondisi demikian masyarakat Jepang lebih mudah melalui masa transisi berhuni dari hunian horisontal ke hunian vertikal.

\section{UCAPAN TERIMA KASIH}

Penulis menghaturkan terima kasih kepada Pemerintah Indonesia atas dana beasiswa program Sandwich-Like 2010 melalui Dirjen DIKTI - Kementrian Pendidikan Nasional Indonesia. Selanjutnya, terima kasih kepada Program Doktor - Institut Teknologi Bandung, Indonesia dan Graduate School of Engineering Chiba University, Jepang, atas dukungannya bagi pelaksanaan program ini, serta Binus University atas pemberian ijin mengikuti kegiatan ini sehingga penulis mendapat kesempatan untuk melakukan kegiatan penelitian dan studi banding di Jepang.

\section{DAFTAR PUSTAKA}

Locher, Mira. (2010). Traditional Japanese Architecture: An Exploration of Elements and Forms. Tokyo: Tuttle Publishing.

Rapoport, Amos. (1969). House, Form and Culture. New York: Prentice-Hall.

Soeroto, Myrtha. (2003). Dari Arsitektur Tradisional Menuju Arsitektur Indonesia. Jakarta: Ghalia Indonesia.

Tokyo Metropolitan Government. (1987). A Historical Review of Japan's Housing Policy. Tokyo: The U.N. International Year of Shelter for the Homeless. 